\title{
A simple method of determining the duration of torsional oscillations
}

\section{R. W. Wood}

To cite this article: R. W. Wood (1895) A simple method of determining the duration of torsional oscillations, Philosophical Magazine Series 5, 40:245, 395-396, DOI:

10.1080/14786449508620784

To link to this article: http://dx.doi.org/10.1080/14786449508620784

曲 Published online: 08 May 2009.

Submit your article to this journal $\lceil\pi$

Џ Article views: 2

Q View related articles $\asymp$ 
ment on the north side of the central valley, though it is noted on a more limited scale in a few localities farther south. It is well exposed in the cliff. 3 miles north of Peel, but the finest sections are in the interior in Sulby Glen, where the structure has a thickness of some hundreds of feet, and runs continuously about north-north-east for 5 miles, with a probable extension southward for 3 miles farther, and also eastward for other 4 miles. It is usually flanked by gritty flags on one side, and by dark clay-slates on the other. It is affected by a strain-slip clearage later than the brecciation, and several igneous dykes which intersect it are affected. by the same cleavage, though not by the brecciation-movement.

East of Sulby Glen the structure extends towards Ramsey, at first in a horizontal spread over a mile in width, and afterwards in a series of comparatively narrow subparallel bands, and it is suggested that we are dealing here with the emergence of a deformed plane. The structure is continued eastward into the hill overlooking Ramsey, beyond which it is cut off by the sea. In this locality, as elsewhere, the sections show the gradual smashing into fragments of highly contorted strata until every trace of the original bedding is lost, and a 'crush-conglomerate' with lenticular and partly rounded inclusions is formed.

The rocks described in Mr. Watts's Appendix are grouped in four classes. Firstly, the grits and slates which have been crushed but have not been converted into erush-conglomerates; secondly, the crush-conglomerates themselves, and the fragments which they contain; thirdly, the dykes of decomposed dolerite (greenstone) and fresh later dolerite which penetrate the conglomerate; fourthly, a portion of the crush-conglomerate metamorphosed by these intrusions.

The chief point of interest is brought out by the examination of the fragments in the conglomerate. All stages of crushing may be traced, until the grit-fragments have a structure which is a mere miniature of the crush-conglomerate itself; that is to say, if the crush-conglomerate be regarded as made of 'fragments' of hard rocks enclosed in crushed 'matrix' of soft rocks, a host of intermediate varieties with varying resistances will occur. Whether any particular one of these varieties shall pass into 'fragments' or 'matrix' under the crushing will depend upon the amount of the crushing force and upon the association (paragenesis) of the material brought togetber to be crushed.

\section{Intelligence and Miscellaneous Articles.}

\section{A SIMPLE METHOD OF DETERUINING THE DURATION OF} TORSIONAL OSCILLATIONS. BY R. W. WOOD.

TN what follows I wish to describe a method by which the time of I torsional oscillations may be conveniently observed, for instance that of a magnet in determining the horizontal intensity of terrestrial magnetism. The usual methods labour under the drawback that the watch and the oscillating body cannot be simultaneously observed. In the present method the watch is brought into the field of view of the telescope with which the vibrations are observed. 
A small light mirror is fastened with wax to the ribrating body in the usual way, and a telescope is sighted at a distance of about two metres. Between the telescope and the mirror is fixed near the latter a thin plane glass, silvered by means of Bïttger's solution, making an angle of $45^{\circ}$ with the rertical. This must refluct more light than it transmits.

A watch is placed on a table below the mirror so that its image reflected from the silvered surface is distinctly visible in the field of view of the telescope. The watch must be brightly lighted by a lamp, and another lamp so placed near the telescope that its rays passing through the transparent coating are reflected by the small mirror into the telescope. On looking through the telescope after the body has been made to oscillate, we see the second-hand strongly magnified, while at each oscillation the small vibrating mirror gives a short flash in the field of view. The image of the secondhand moves in the opposite direction to the hand itself. By following the motion of the hand it is easy to accurately determine the time of the fiash to a quarter of a second. If the oscillations are rapid, it is of course more convenient only to observe the time of every fifth or tenth oscillation. After a few observations we linow when the following is to be expected, and by fixing the ere on the division of the dial where the second-hand will be at the moment of the flash, it is possible to determine the time to within a quarter of a second. We soon get accustomed to the backward motion of the index, and the rending is as easy as the ordinary one.

Instead of the semitransparent silver mirror an ordinary opaque plane mirror may be used (metal of course is best), if it is so arranged that the mirror on the oscillating body is visibje just above or below its edge.-Wiedemann's Anralen, No. 9, 1895.

\section{ON THE INCONSTANOY OF THE POTENTIAL REQUIRED FOR A} SPARK. BY G. JAUMANN.

The author summarizes as follows the results of his iniestigation:-

I. Sparks alter the path through which they pass; strong ones in an unfavourable sense, and weak ones often in a farourable sense. The path spontaneously recovers from this after-action in the course of some hours.

II. By avoiding the smallest variations of force very high potentials may be obtained.

III. When the conditions for a discharge are not quite satisfied, the discharge takes place after a delay of a few seconds to several minutes. During this retardation there is a prelininary process of discharge which itself is no rea] discharge.

IV. During this retardation the excitiug influence of variations of force can be demonstrated in an incontestable manner.

V. A moderate variation of force does not produce the spark at once, but only after $0 \cdot 1-5$ seconds. It only accelerates the preliminary process and shortens therefore the retardation.-Wiedemann's Annalen, No. 8, 1895. 